REPORTS OF MORPHOLOGY
Official Journal of the Scientific Society of Anatomists,
Histologists, Embryologists and Topographic Anatomists
of Ukraine
journal homepage: https://morphology-journal.com

\title{
Features of translation of some rarely used anthropometric terms from Ukrainian into English
}

Cherepakha O.L., Gadzhula N.G., Hnenna V.O., Hrytsenko A.S.

National Pirogov Memorial Medical University, Vinnytsia, Ukraine

\section{ARTICLE INFO}

Received: 15 June, 2020

Accepted: 20 July, 2020

UDC: $811.161 .2 / .111: 572$

\section{CORRESPONDING AUTHOR}

e-mail: cherepakha79@gmail.com

Cherepakha O.L.

\begin{abstract}
Nowadays, anthropometric researches have confidently taken its place in medicine. They are useful not only for health assessment, but also are used in many fields: forensic medicine (to estimate the age of the subject), forensic dentistry (it is an interdiscipline of forensic medicine and dentistry) for the identification of individual and age estimation, dentistry (anthropometric diagnostic methods of dentognathic anomalies and deformations, and there is a potential correlation among number of teeth, chewing ability and anthropometric profile), pediatrics, obstetrics and gynecology, as well as for the diagnosis of overweight (important indicators of nutritional status in the children and adults), for sports control and for the standardization purpose. The symptoms of many diseases are expressed in anthropometric changes. Unfortunately, in Ukraine there is still no generally accepted translation of anthropometric terms from Ukrainian into English. Often for the same medical anthropological term, different names and definitions are used in foreign scientific works. Therefore, the aim of the work was to unify and standardize the translation of rarely used anthropometric terms from Ukrainian into English, as well as determination of the place of the anthropometric point measurement and its schematic representation. We have used the standardized techniques proposed by Shaparenko P.P. and Burikh, M.P. (2000), set out in the "Anthropometric data analysis sets manual" (1994), in the works of Hobbs P.C. (1975) and Brinkley, J.F with co-authors (2016), where some anthropometric terms were described that are used when measuring the head, determining the height above the floor of some points of the trunk and upper limb of a person, and anthropometric parameters of the hand. The conclusion is made about the correctness of the proposed translation from Ukrainian into English, considering the specialized terminology. We hope that in the future this list will be supplemented with the new terms related to measurements of the auricle, upper and lower extremities.

Key words: anthropometric terminology, anthropometric measurements, translation, English language.
\end{abstract}

\section{Introduction}

Anthropometry is directly or indirectly related to all branches of medical science. Nowadays, anthropometric researches have confidently taken its place in medicine. So they are useful not only for health assessment, but also are used in many fields: forensic medicine (to estimate the age of the subject) [13], forensic dentistry (it is an interdiscipline of forensic medicine and stomatology) for the identification of individual and age estimation [24], dentistry (anthropometric diagnostic methods of dentognathic anomaly, and there is potential correlation among number of teeth, chewing ability and anthropometric profile) $[7,9,29]$, pediatrics, obstetrics and gynecology [17, $21,27]$, as well as for the diagnosis of overweight (important indicators of nutritional status in the children and adults) [11, 16, 20], for sports control [22] and for the standardization purpose $[3,15,23,26,30]$. The symptoms of many diseases are expressed in anthropometric changes [12].

So on the basis of the research center of the National Pirogov Memorial Medical University, Vinnytsya, as a part of the general university scientific project "Development of normative health criteria of the various age and sex groups of the population based on the study of anthropogenetic and physiological characteristics of the body in order to determine markers of multifactorial diseases", for many years, scientists and employees working in different departments of the university have been performing 
scientific work and using anthropometric terminology.

Today, scholars often have problems working with anthropometric articles and textbooks in English. To date, we have published 2 methodological articles $[5,6]$ which include the translation from Ukrainian into English of the most commonly used anthropometric terms with a description of the place and methods of determining the corresponding anthropometric points or sizes and also figures that schematically show determination of human head parameters.

Unfortunately, there is still no generally accepted unified use of the translation of anthropometric terms from Ukrainian into English on the territory of Ukraine.

Therefore, the aim of the work was to standardize and unify the translation from Ukrainian into English of some anthropometric terms that are rarely used.

\section{Materials and methods}

Thus, to determine some anthropometric points and parameters of the human head measure the following:

bitragion - coronal arc: the surface distance between the right and left tragion landmarks across the top of the head is measured with a tape (tape tension sufficient to flatten hair). The head is in the Frankfort plane (Fig. 1) [2, 25];

bitragion breadth: as a result of this measurement, we obtain the digital value of the breadth of the head which is determined by measuring the distance from the right to the left tragion with a head caliper (Fig. 2) [2, 25];

tragion to top of head (vertex): measure the distance from the tragion to the vertex $[2,25]$;

palpebral fissure length: measure the horizontal length of the eye fissure, from corner to corner. (i.e., as a result, we receive the digital value of the horizontal dimension, or width, of the palpebral fissure) (Fig. 3), [4, 25];

interocular distance: carry out a horizontal measurement between the inner corners of the eyes, as a result of which a digital value of the inner distance between the eyes is obtained [2, 25];

menton-crinion length: measure the distance from the bottom surface of the chin to the midpoint of the hairline. Not measured on bald and balding [2, 25];

minimum frontal arc these measurements are performed using a tape - measure the arc across forehead between points of the greatest indentation of temporal crests (Fig. 4), [14, 25];

maximum nose breadth: researcher is placing recording parts of the caliper on broadest part of nose then moving horizontally across to other side of nose, measurement of maximum nose breadth without applying a pressure (Fig. 5), [14, 25];

upper facial height: this measurement is designed to principally capture the vertical length or height of the upper portion of the face or viscerocranium. Despite its name, this measurement contains segments of the classically defined middle and lower facial thirds which are determined by measuring the straight distance between nasion and stomion. (Fig. 6), [4, 25];

lower facial height: this measurement is designed to principally capture the vertical length or height of the lower portion of the face or viscerocranium. Straight distance between subnasale and gnathion is measured. (Fig. 7), $[4,25]$;

upper lip height: vertical measurement designed to capture the length or height of the entire upper lip including the skin and vermillion segments. Other common names for this measurement include: total upper lip height or length. The upper lip height is determined by measuring the distance between subnasale and stomion [4, 25];

lower lip height: vertical measurement designed to capture the length or height of the entire lower lip including the skin and vermillion segments. Other common names for this measurement include: total lower lip height or length. The lower lip height is determined by measuring the distance between stomion and sublabiale [4, 25];

ear length: measure the distance from the highest to the lowest points on a line parallel to the long axis of the ear [2, 25];

ear breadth: measure the maximum breadth of the right ear, which is perpendicular to its long axis [2, 25];
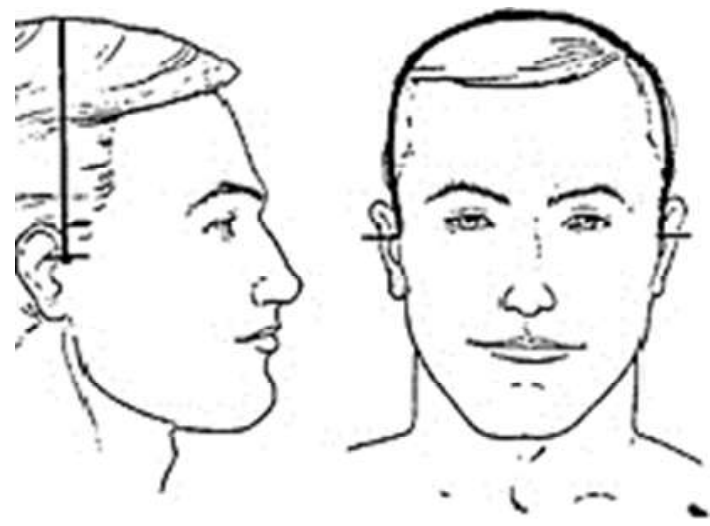

Fig. 1. Поперечна дуга. Bitragion - Coronal Arc.

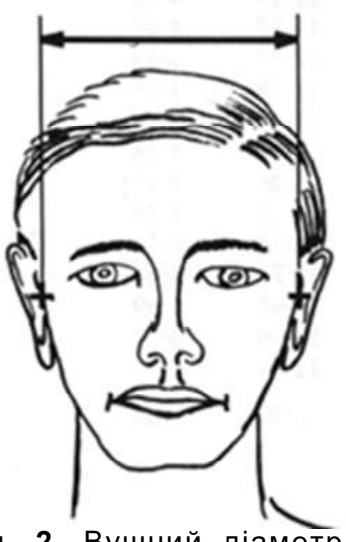

Fig. 2. Вушний діаметр. Bitragion Breadth.

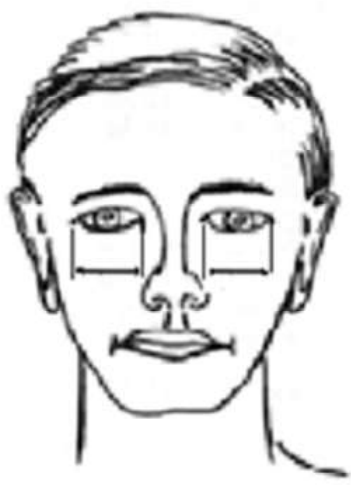

Fig. 3. Ширина очної щілини. Palpebral fissure length. 


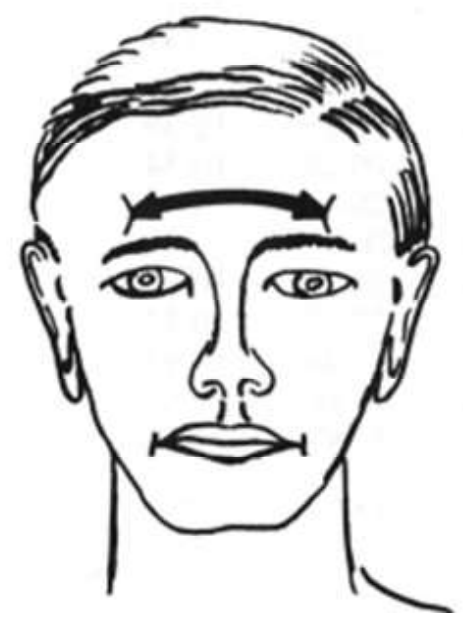

Fig. 4. Мінімальна фронтальна ширина. Minimum Frontal Arc.

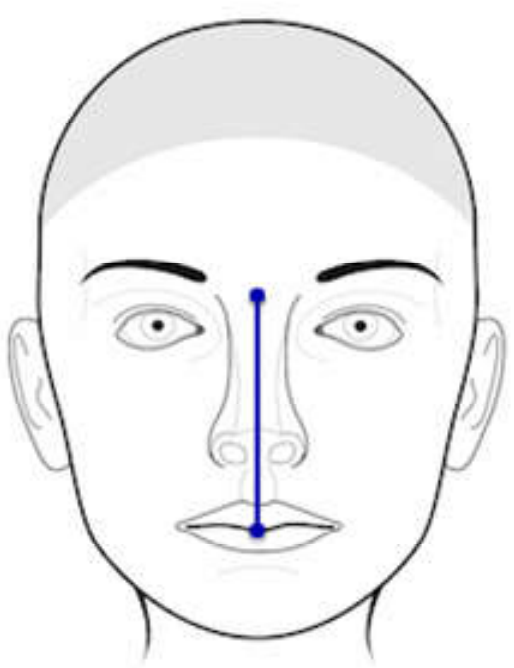

Fig. 6. Висота верхньої частини обличчя. Upper Facial Height.

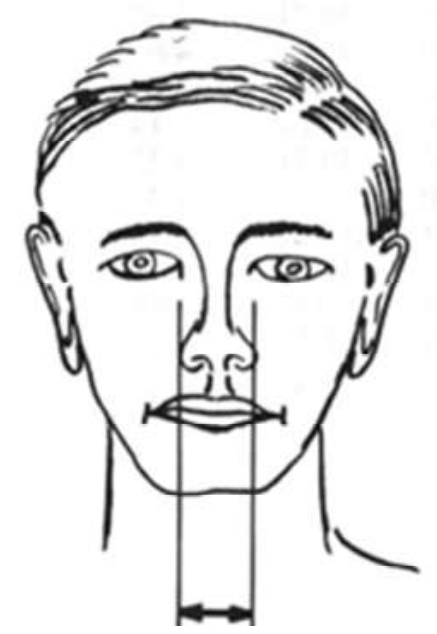

Fig. 5. Максимальна ширина носа. Maximum Nose Breadth.

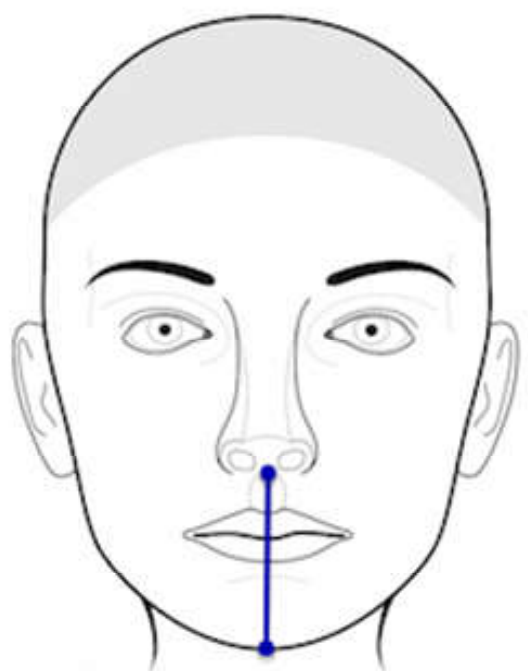

Fig. 7. Висота нижньої частини обличчя. Lower Facial Height.

height of the midpoint of the lower edge of the breast bone from the floor [2, 25];

tenth rib height: established by measuring the vertical distance between a standing surface and the tenth rib landmark at the bottom of the right side of the rib cage [2, 25];

iliospinale height: established by measuring the vertical distance from the floor to the left iliospinale $[2,25]$;

Iliocristale height: established by measuring the vertical distance between a standing surface and the iliocristale landmark on the top of the right side of the pelvis [2, 25];

cervicale height: established by measuring the vertical distance between a standing surface and the cervicale landmark on the spine at the base of the neck [2, 25];

It should be noted that in the study, the subject should stand erect, looking straight ahead, his head should be in the Frankfort plane, shoulders and upper extremities should be relaxed. All measurements are performed with an anthropometer according to the method described by Shaparenko P.P. and Burikh, M.P. in 2000 [25] and by "Anthropometric data analysis sets manual" (1994) [2].

To determine the height of the anthropometric points of the upper

It should be noted that ear length and ear breadth are measured with a sliding caliper. During research, the subject should sit erect looking straight ahead. The head is in the Frankfort plane (the Frankfurt plane is a plane formed by drawing a straight horizontal line from the top of the ear canal to the inferior margin of the eye along either side of the human skull provided that the median plane of the head is vertical). The researcher carries out measurements with a caliper without applying a pressure. All measurements are performed with a caliper or a tape according to the method described by Hobbs in 1975 [14], set out in the "Anthropometric data analysis sets manual" 1994 [2], in the work of Shaparenko P.P. and Burikh, M.P. in 2000 [25], as well as by Brinkley, J. F et al., who provided the appropriate methodology in their work in 2016 [4].

To determine the height of the torso point's locations above a standing surface measure the following:

substernale height: established by measuring the limb above a standing surface and the anthropological parameters of the human hand measure the following:

acromion height: established by measuring the vertical distance between a standing surface and the acromion landmark on the tip of the right. The subject should stand upright looking straight ahead. The measurement is performed with an anthropometer [2, 25];

radial-stylion length: established by measuring the distance between the radiale landmark on the right elbow and the stylion landmark on the right wrist. It is measured with a beam caliper held parallel to the long axis of the forearm. Subject stands with the arms relaxed at the sides. The hand and fingers are held straight in line with the long axis of the forearm [2, 25];

hand length: established by measuring the length of the right hand between the stylion landmark on the wrist and the tip of the middle finger. The subject places the palm on a table with the fingers together, and the thumb 
abducted. The middle finger is parallel to the long axis of the forearm. The measurement is carried out with a Poech sliding caliper [2, 25];

palm length: established by measuring the distance from the base of the hand to the furrow where the middle finger folds upon the palm [2, 25];

hand breadth at metacarpale: established by measuring the breadth of the right hand between the landmarks at metacarpale II and metacarpale $\mathrm{V}$ The subject places the palm on a table, the fingers together and the thumb abducted. The middle finger is parallel to the long axis of the forearm. The measurement is carried out with a sliding caliper [2, 25];

Currently, we have proposed a number of unified anthropometric terms in Ukrainian, which are rarely used with their translation into English, as well as the places of the anthropometric point determination and its schematic representation.

This list was developed by us based on the following scientific sources: Anthropometry and systems of topographic and anatomical coordinates of the human body [25], Anthropometric data analysis sets manual [2], The Face Base Consortium: a comprehensive resource for craniofacial researchers [4], An anthropometric survey of 500 Royal air force aircrew heads [14].

\section{Results}

The obtained measurements of some anthropometric parameters of the head and upper limb, as well as the determination of the location of the head and torso points of a person, make it possible to use the following scientific terms in the process of translation from Ukrainian into English:

\section{Anthropometric points of the head}

Поперечна дуга - Bitragion - coronal arc (landmarks involved - tragion: the point located at the notch just above the tragus of the ear. This point corresponds approximately to the upper edge of the ear hole. Vertex: highest point on the convexity of the calvarium measured from the Frankfurt plane (auriculo-orbital plane) (Fig. 1).

Вушний діаметр - Bitragion breadth (landmarks involved - tragion (Fig. 2)).

Bucoma голови - Tragion to top of head (vertex) (landmarks involved - vertex and tragion (Fig. 3)).

Ширина очної щілини - Palpebral fissure length (landmarks involved - endocanthion: apex of the angle formed at the inner corner of the palpebral fissure where the upper and lower eyelids meet. Exocanthion: apex of the angle formed at the outer corner of the palpebral fissure where the upper and lower eyelids meet.)

Міжочноямкова ширина - Interocular distance (landmarks involved - endocanthion: the point of the medial angle of the eye which is located medially from caruncula lacrimalis.).

Фізіологічна довжина обличчя - Menton-crinion length.
Мінімальна лобова ширина - Minimum frontal arc (Fig. 4).

Максимальна ширина носа - Maximum nose breadth (landmarks involved - alare: most lateral point on the nasal ala (Fig. 5)).

Bucoma верхньої частини обличчя - Upper facial height (landmarks involved - nasion: midline point where the frontal and nasal bones contact (nasofrontal suture). Soft tissue nasion corresponds to the underlying bony landmark. Stomion: the point of contact in the midsagittal plane between the upper and lower lips. (Fig. 6)).

Bucoma нижньої частини обличчя - Lower facial height (landmarks involved - subnasale: midline point marking the junction between the inferior border of the nasal septum and the cutaneous upper lip. It is the apex of the nasolabial angle. Gnathion: Midline point on the inferior border of the mandible. It corresponds to the underlying bony landmark (Fig. 7)).

Bucoma верхньої губи - Upper lip height (landmarks involved - subnasale and stomion).

Buсота нижньої губи - Lower lip height (landmarks involved - sublabiale: it is midpoint along the inferior margin of the cutaneous lower lip (labiomental sulcus) and stomion).

Фізіономічна довжина вуха - Ear length.

Фізіономічна ширина вуха - Ear breadth.

The following terms should be used to define the height of torso points when translated into English:

Нижньогрудинна - Substernale height.

Нижньореберна передня - Tenth rib height.

Клубово-остиста передня - Iliospinale height.

Клубово-гребнева найвища - lliocristale height.

Buсота шийної точки - Cervicale height.

To determine the name of the height of the anthropometric point's location of the upper limb and anthropological measurements of the hand, when translated into English, the following terms should be used:

\section{Bucoma плечової точки - Acromion height.}

Шилоподібна променева - Radiale-stylion length.

Довжина кисті - Hand length.

Довжина долоні - Palm length.

Ширина кисті або поперечний діаметр - Hand breadth at metacarpale.

\section{Discussion}

Often, different terminology is used for the scientific definition of the same point, even in English scientific medical articles. So S. Tripathi with co-authors [28] and A. Dwivedi with co-authors [8] have used in their articles next terms: "interalar width" instead of "maximum nose breadth" and "intercanthal width/distance" instead of "interocular distance". Annelyse Cristine Ballin and coauthors [3] when evaluating the anthropometric measures of Caucasian noses of people living in the city of Curitiba have used the term "intercanthal distance" instead of "interocular distance" and the term "alar distance" instead 
of "maximum nose breadth". In Ukrainian, this term sounds like "міжочноямкова ширина", reflecting the correctness of the meaningful use of the term in English "interocular distance" and also term "максимальна ширина носа" will be translated into English "maximum nose breadth".

Ma Huan and co-authors [18] when evaluating effect of aging in periocular appearances in Chinese Han population have used in their article the term "intercanthal width" instead of "interocular distance" and "outercanthal width" instead of "biocular breadth" (unified term used in our previous article [6]). In Ukrainian, this term sounds like "зовнішньо очна ширина", reflecting the correctness of the meaningful use of the term in English "biocular breadth".

S.M. Weinberg and co-authors [31] when describing hypertelorism and orofacial clefting have used in their article the term "intercanthal width" instead of "interocular distance".

Kamlesh B. Patel and co-authors [19] when describing fronto-orbital advancement for metopic synostosis have used in their article the term "intercanthal distance", instead of "interocular distance".

C.L. Fry and co-authors [10] when describing features spanning the morphologic range in the spectrum of the Latino eyelid have used the term "horizontal fissure length" instead of "palpebral fissure length". In Ukrainian, this term sounds like "ширина очної щілини", reflecting the correctness of the meaningful use of the term in English "palpebral fissure length".

Olalekan Agbolade and co-authors [1] when investigating three-dimensional (3D) soft-tissue craniofacial variation, with relation to ethnicity, sex and age variables in British and Irish white Europeans have used in their article the term "intercanthal width" instead of

\section{References}

[1] Agbolade, O., Nazri, A., Yaakob, R., Ghani, A. A., \& Cheah, Y. K. (2020). Morphometric approach to 3D soft-tissue craniofacial analysis and classification of ethnicity, sex, and age. PLoS One, 15(4): e0228402. doi: 10.1371/journal.pone.0228402

[2] Anthropometric data analysis sets manual [Electronic resource] by data of Human Systems Information Analysis Center / the United States Department of Defense - 1994. - http:// mreed.umtri.umich.edu/mreed/downloads/anthro/ansur/ ADAS-Dimension_Definitions.pdf

[3] Ballin, A. C., Carvalho, B., Dolci, J. E. L., Becker, R., Berger, C., \& Mocellin, M. (2018). Anthropometric study of the caucasian nose in the city of Curitiba: relevance of population evaluation. Brazilian Journal Otorhinolaryngology, 84(4), 486-493. doi: 10.1016/j.bjorl.2017.06.004

[4] Brinkley, J. F., Fisher, Sh., Harris, M. P., Holmes, G., Hooper, J. E., Jabs, E. W., ... Chai, Y. (2016). The Face Base Consortium: a comprehensive resource for craniofacial researchers. Development, 143(14), 2677-2688. doi: 10.1242/dev.135434

[5] Cherepakha, O. L. (2014). Особливості перекладу антропометричної термінології з української на англійську мову. Вісник морфології, 20(2), 298-303.

[6] Cherepakha, O. L., \& Terehovska, O. I. (2015). Уніфіковані традиційні антропометричні терміни та їх еквіваленти англійською мовою з перекладом українською мовою. "interocular distance" and "biocular width" instead of "biocular breadth" (unified term used in our previous article [6]).

Gloria Staka and co-authors [26] тa Saurab S. Virdi and co-authors [30] have used in their article the term "nasal width" (the straight distance between right and left alare) instead of "maximum nose breadth".

If you are translating from Ukrainian into English without terminology knowledge you will get wrong translation.

As an example, translation of the term "фрізіологічна довжина голови" into English you will get "physiologic head length" instead of "menton-crinion length" or translation of the term "вушний діаметр" уоu will get "ear diameter" instead of "bitragion breadth".

In the future, it is planned to revise and supplement the list of terms with new terms regarding measurements of the auricle, upper and lower extremities of a person.

\section{Conclusions}

Thus, the given traditional unified anthropometric terms concerning anthropometric points and measurements of the head, trunk and several points of the upper limb with their translation into Ukrainian, as well as the definition of the place of anthropometric points measurement and their schematic representations, namely bitragion, coronal arc, bitragion breadth, tragion to top of head (vertex), horizontal palpebral aperture, interocular distance, menton-crinion length, minimum frontal arc, maximum nose breadth, upper facial height, lower facial height, upper lip height, lower lip height, ear length, ear breadth, substernale height, tenth rib height, iliospinale height, iliocristale height, acromion height, radiale-stylion length, hand length, palm length and hand breadth at metacarpale.

Вісник морфолоаії, 21(2), С.515-518.

[7] Culebras-Atienza E, Silvestre FJ, Silvestre-Rangil J. (2018). Possible association between obesity and periodontitis in patients with Down syndrome. Med. Oral. Patol. Oral. Cir. Bucal., 23(3), 335-343. doi: 10.4317/medoral.22311

[8] Dwivedi, A., Yadav, N. S., \& Mishra, S. K. (2017). Inter-Canthal and Inter Alar Distance as a Predictor of Width of Maxillary Central and Lateral Incisor - An In Vivo Study. Annals of Medical and Health Sciences Research, 7, 276-279.

[9] Farsi, D. J., Elkhodary, H. M., Merdad, L. A., Farsi, N. M., Alaki, S. M., Alamoudi, N. M., ... Alolayyan, M. A. (2016). Prevalence of obesity in elementary school children and its association with dental caries. Saudi Med. J., 37(12), 1387-1394. doi: 10.15537/ smi.2016.12.15904

[10] Fry, C. L., Naugle, T. C., Cole, Sh. A., Gelfond, J., Chittoor, G., Mariani, A. F., ... Voruganti, V. S. (2017). The Latino eyelid: anthropometric analysis of a spectrum of findings. Ophthalmic Plastic and Reconstructive Surgery, 33(6), 440-445. doi: 10.1097/IOP.0000000000000821

[11] Gažarová M, Galšneiderová M, Mečiarová L. (2019). Obesity diagnosis and mortality risk based on a body shape index (ABSI) and other indices and anthropometric parameters in university students. Rocz. Panstw. Zakl. Hig., 70(3), 267275. doi: 10.32394/rpzh.2019.0077 
[12] G?a-Horta, T., Beinner, M. A., Gazzinelli, A., Mendes, M. S. F., \& Velasquez-Melendez, G. (2018). Anthropometric changes and their effects on cardiometabolic risk factors in rural populations in Brazil. Cien. Saude Colet., 23(5), 1415-1423. doi: 10.1590/1413-81232018235.19552016

[13] Haghanifar, S., Ghobadi, F., Vahdani, N., \& Bijani, A. (2019). Age estimation by pulp/tooth area ratio in anterior teeth using cone-beam computed tomography: comparison of four teeth. J. Appl. Oral. Sci., e20180722. doi: 10.1590/1678-7757-20180722

[14] Hobbs, P. C. (1975). An anthropometric survey of 500 Royal Air Force aircrew heads - Farnborough: by the Royal Air Force Institute of Aviation Medicine and the Royal Aircraft Establishment

[15] Japatti, S. R., Engineer, P. J., Reddy, B. M., Tiwari, A. U., Siddegowda, C. Y., \& Hammannavar, R. B. (2018). Anthropometric Assessment of the Normal Adult Human Ear. Ann. Maxillofac. Surg., 8(1), 42-50. doi: 10.4103/ ams.ams_183_17 (4)

[16] JJaroszynnski, A., Dereziński, T., Jaroszyńska, A., Zapolski, T., Wąsikowska, B., Wysokiński, A. ... Horoch, A. (2016). Association of anthropometric measures of obesity and chronic kidney disease in elderly women. Ann. Agric. Environ. Med., 23(4), 636-640. doi: 10.5604/12321966.1226859

[17] Kesterke, M. J., Raffensperger, Z. D., Heike, C. L., Cunningham, M. L., Hecht, J. T., Kau, C. H., ... Weinberg, S. M. (2016). Using the 3D Facial Norms Database to investigate craniofacial sexual dimorphism in healthy children, adolescents, and adults. Biol. Sex Differ. 7:23. doi: 10.1186/s13293-016-0076-8

[18] Ma, H., Chen, Y., Cai, X., Tang, Z., Nie, C., \& Lu, R. (2019). Effect of aging in periocular appearances by comparison of anthropometry between early and middle adulthoods in Chinese Han population. Journal of Plastic, Reconstructive and Aesthetic Surgeons, 72(12), 2002-2008. doi: 10.1016/ j.bjps.2019.07.030

[19] Patel, K. B., Skolnick, G. B., \& Mulliken, J. B. (2016). Anthropometric Outcomes following Fronto-Orbital Advancement for Metopic Synostosis. Plastic and Reconstructive Surgery, 137(5), 1539-1547. doi: 10.1097/ PRS.0000000000002129

[20] Patnaik L, Pattnaik S, Rao EV, Sahu T. (2017) Validating Neck Circumference and Waist Circumference as Anthropometric Measures of Overweight. Obesity in Adolescents Indian Pediatr., 54(5), 377-380. doi: 10.1007/s13312-017-1110-6

[21] Phelan, S., Clifton, R. G., Haire-Joshu, D., Redman, L. M., Van Horn, L., Evans, M. ... Pi-Sunyer, X. (2020). One-year postpartum anthropometric outcomes in mothers and children in the LIFE-Moms lifestyle intervention clinical trials. Int. J. Obes. (Lond)., 44(1), 57-68. doi: 10.1038/s41366-019-04104

[22] Pizzigalli, L., Cremasco, M. M., Torre, A.L.A., Rainoldi, A., \& Benis, R. (2017). Hand grip strength and anthropometric characteristics in Italian female national basketball teams. $J$. Sports Med. Phys. Fitness., 57(5), 521-528. doi: 10.23736/ S0022-4707.16.06272-1

[23] Sadacharan, C. M. (2016). Vertical and horizontal facial proportions of Indian American men. Anatomy \& Cell Biology., 49(2), 125-131. doi: 10.5115/acb.2016.49.2.125

[24] Schmeling, A., Dettmeyer, R., Rudolf, E., Vieth, V., \& Geserick, G. (2016). Forensic Age Estimation. Dtsch. Arztebl. Int., 113(4), 44-50. doi: 10.3238/arztebl.2016.0044

[25] Shaparenko, P. P., \& Burikh, M. P. (2000). Антропометрія та системи топографоанатомічних координат тіла людини. Вінниця: ВДМУ.

[26] Staka, G., Asllani-Hoxha, F., \& Bimbashi V. (2017). Facial anthropometric norms among Kosovo - Albanian adults. Acta Stomatol. Croat., 51(3), 195-206. doi: 10.15644/asc51/3/3

[27] Szczuko M, Skowronek M, Zapalowska-Chwyc M, Starczewski A. (2016) Quantitative assessment of nutrition in patients with polycystic ovary syndrome (PCOS). Rocz. Panstw. Zakl. Hig., 67(4), 419-426. PMID: 27925712

[28] Tripathi, S., Singh, R. D., Chand, P., Kumar, L., \& Singh, G. K. (2018). A study to correlate various facial landmarks with intercanine distance. Indian Journal of Dental Research, 29(4), 440-444. doi: 10.4103/ijdr.IJDR_80_17

[29] Vazquez-Casas, I., Sans-Capdevila, O., Moncunill-Mira, J., \& Rivera-Bar, A. (2020). Prevalence of sleep-related breathing disorders in children with malocclusion. J. Clin. Exp. Dent., 12(6), 555-560. doi: 10.4317/jced.56855

[30] Virdi, S., Saurab, Wertheim, D., \& Naini, F. B. (2019). Normative anthropometry and proportions of the Kenyan-African face and comparative anthropometry in relation to African Americans and North American Whites. Maxillofac. Plast. Reconstr. Surg., 41(1), 9. doi: 10.1186/s40902-019-0191-7

[31] Weinberg, S. M., Leslie, E. J., Hecht, J. T., Wehby, G. L., Deleyiannis, F. W. B., Moreno, L. M., ... Marazita, M. L. (2017). Hypertelorism and Orofacial Clefting Revisited: An Anthropometric Investigation. Cleft Palate-Craniofacial Journal, 54(6), 631-638. doi: 10.1597/15-256

[32] Zhao, K., Hohmann, A., Chang, Y., Zhang, B., Pion, J., \& Gao, B. (2019). Physiological, Anthropometric, and Motor Characteristics of Elite Chinese Youth Athletes From Six Different Sports. Front. Physiol., 10, 405. doi: 10.3389/ fphys.2019.00405

\section{ОСОБЛИВОСТІ ПЕРЕКЛАДУ З УКРАЇНСЬКОЇ МОВИ НА АНГЛІЙСЬКУ ДЕЯКИХ АНТРОПОМЕТРИЧНИХ ТЕРМІНІВ, ЩО РІДКО ВИКОРИСТОВУЮТЬСЯ}

Черепаха О.Л., Гаджула Н.Г., Гненна В.О., Гриценко А.С.

На теперішній час антропометричні дослідження впевнено зайняли свою нішу в медицині. Тож вони корисні не тільки для оцінки стану здоров'я, але й використовуються в багатьох галузях: судова медицина (для оцінки віку особи, що досліджується), судова стоматологія (це дисципліна на стику судової медицини та стоматології) для ідентифрікації особистості та оцінки віку, стоматологія (антропометричні методи діагностики зубо-щелепної аномалії, а також існує потенційна кореляція між кількістю зубів, жувальними можливостями та антропометричним профілем), педіатрії, акушерства та гінекології, а також для діагностики зайвої ваги (важливі показники харчового статусу у дітей та дорослих), для спортивного контролю та з метою стандартизації. Симптоми багатьох захворювань знаходять своє відображення в змінах антропометричних показників. На жаль, в Україні досі немає загальноприйнятого перекладу антропометричних термінів з української на англійську мову. Нерідко в зарубіжних наукових роботах для одного і того ж медичного антропологічного терміну використовують різні назви і визначення. Тому метою роботи було уніфрікація і стандартизація перекладу з української мови на англійську деяких антропометричних термінів, які рідко використовуються, а також уточнення місця вимірювання антропометричної точки та їі схематичне зображення. Використовуючи стандартизовані методики, запропоновані Шапаренко П.П. та Бурих М.П. (2000), викладені у Посібнику аналізу антропометричних даних (1994), Hobbs P.C. (1975), a 
також у роботі Brinkley, J.F. зі співавторами (2016) були описані деякі антропометричні терміни, котрі використовують при вимірах голови, визначенні висоти знаходження деяких точок верхньої кінцівки і тулуба людини над підлогою, а також антропометричних параметрів кисті. Зроблено висновок про правильність і коректність запропонованого перекладу з української мови на англійську, з огляду на спеціалізованість термінології. В подальшому цей перелік буде доповнено новими термінами, що стосуються вимірів вушної раковини, верхніх і нижніх кінцівок.

Ключові слова: антропометрична термінологія, антропометричні вимірювання, переклад, англійська мова.

ОСОБЕННОСТИ ПЕРЕВОДА С УКРАИНСКОГО ЯЗЫКА НА АНГЛИЙСКИЙ НЕКОТОРЫХ АНТРОПОМЕТРИЧЕСКИХ ТЕРМИНОВ, КОТОРЫЕ РЕДКО ИСПОЛЬЗУЮТСЯ

Черепаха Е.Л., Гаджула Н.Г. Гненна В.О., Гриценко А.С.

В настоящее время антропометрические исследования уверенно заняли свою нишу в медицине. Поэтому они полезны не только для оценки состояния здоровья, но и используются во многих отраслях: судебная медицина (для оценки возраста исследуемого человека), судебная стоматология (это дисциплина на стыке судебной медицины и стоматологии) для идентификации личности и оценки возраста, стоматология (антропометрические методы диагностики зубо-челюстной аномалии, а также существует потенциальная корреляция между количеством зубов, жевательными возможностями и антропометрическим профилем), педиатрии, акушерства и гинекологии, а также для диагностики лишнего веса (важные показатели пищевого статуса у детей и взрослых), для спортивного контроля и с целью стандартизации. Симптомы многих заболеваний выражаются в антропометрических изменениях. К сожалению, в Украине до сих пор нет общепринятого перевода антропометрических терминов с украинского на английский язык. Нередко в зарубежных научных работах для одного и того же медицинского антропологического термина используют разные названия и определения. Поэтому целью работы было унификация и стандартизация перевода с украинского языка на английский некоторых антропометрических терминов, которые редко используются, а также определения места измерения антропометрической точки и ее схематическое изображение. Используя стандартизированные методики, предложенные Шапаренко П.Ф. и Бурых М.П. (2000), изложенные в Пособии для анализа антропометрических данных (1994), Hobbs P.C. (1975), а также в работе Brinkley, J.F. с соавторами (2016) были описаны некоторые антропометрические термины, которые используют при измерениях головы, определении высоты нахождения некоторых точек верхней конечности и туловища человека над полом, а также антропометрических параметров кисти. Сделан вывод о правильности и корректности предложенного перевода с украинского языка на английский, учитывая специализированность терминологии. В будущем это перечень будет дополнен новыми терминами, касающимися измерений ушной раковины, верхних и нижних конечностей.

Ключевые слова: антропометрическая терминология, антропометрические измерения, перевод, английский язык. 